University of Nebraska - Lincoln

DigitalCommons@University of Nebraska - Lincoln

Papers in the Earth and Atmospheric Sciences

Earth and Atmospheric Sciences, Department

2000

\title{
Spaceborne Microwave Remote Sensing of Arctic Sea Ice During Spring
}

\author{
Sheldon D. Drobot \\ University of Nebraska-Lincoln \\ Mark R. Anderson \\ University of Nebraska-Lincoln, manderson4@unl.edu
}

Follow this and additional works at: https://digitalcommons.unl.edu/geosciencefacpub

Part of the Earth Sciences Commons

Drobot, Sheldon D. and Anderson, Mark R., "Spaceborne Microwave Remote Sensing of Arctic Sea Ice During Spring" (2000). Papers in the Earth and Atmospheric Sciences. 260.

https://digitalcommons.unl.edu/geosciencefacpub/260

This Article is brought to you for free and open access by the Earth and Atmospheric Sciences, Department of at DigitalCommons@University of Nebraska - Lincoln. It has been accepted for inclusion in Papers in the Earth and Atmospheric Sciences by an authorized administrator of DigitalCommons@University of Nebraska - Lincoln. 


\section{Spaceborne Microwave Remote Sensing of Arctic Sea Ice During Spring*}

\section{Sheldon D. Drobot and Mark R. Anderson \\ University of Nebraska-Lincoln}

This paper outlines the fundamental roles sea ice plays during the spring Arctic climate, and it demonstrates the use of passive microwave remote sensing in measuring climatically important sea ice variables during the spring transitional period. It discusses the theoretical concepts underlying passive microwave remote sensing of sea ice, and it summarizes the historical use of satellite microwave radiometry in the Arctic region. In addition, this paper discusses the derivation of climatically important sea ice variables, including sea ice extent, concentration, multiyear ice fraction, and snow melt onset, with additional comments on the precision and accuracy of the remote sensing estimates. It also discusses interannual trends in sea ice extent and presents interannual trends in snow melt onset dates. Finally, this paper provides a brief discussion on the future directions in passive microwave remote sensing of climatically important sea ice variables during the spring transitional period. Key Words: climate, microwave remote sensing, sea ice.

\section{Introduction}

Now covered sea ice plays a critical role in the spring Arctic climate by governing energy absorption across the ocean-atmosphere- ice interface (OAII). During early spring the albedo of a dry snow covered sea ice surface can be as high as 0.98 (Vowinckel and Orvig 1970), limiting energy absorption. However, during snow melt, energy absorption increases dra-

\footnotetext{
* This work was supported at the University of Nebraska-Lincoln by NASA grant NAGW-1266 and NGT5-30175 and by NASA contract NAS5-32392 to the University of Colorado. The SSM/I gridded brightness temperatures obtained on CD-ROM were from the National Snow and Ice Data Center, Boulder, CO.
} 
matically as albedo decreases. The addition of energy further drives melt, setting up a temperature-albedo feedback mechanism that is thought to account for a considerable amount of projected Arctic warming (e.g., Curry et al. 1995). Modelling scenarios suggest this warming could reduce global ice cover by $17 \times 10^{6}$ $\mathrm{km}^{2}$ (IPCC 1998).

It is therefore important to characterize sea ice conditions during the spring transition and understand how variability in sea ice conditions corresponds to variability in climate. Owing to the vast spatial scales, harsh climates, and lack of in situ data, remote sensing is often relied upon to provide sea ice information. Visual imagery can determine many important sea ice variables, but it is limited to cloud-free conditions when sunlight is available. Infrared imagery can also detect sea ice variables, but it is restricted by cloud cover and the strong Polar inversion layer. Microwave remote sensing, with diurnal and nearly all-weather capabilities, is an ideal technique for obtaining sea ice information. Furthermore, microwave interaction theory with sea ice is a reasonably well developed science (e.g., Carsey 1992), with a 20year data record available.

This paper examines spaceborne microwave radiometric observations of sea ice during spring. Specifically, it describes how microwave data are used to determine sea ice extent, ice concentration, and multiyear ice fraction, with a more detailed discussion of the estimation of snow melt onset dates. In addition, it illustrates known sources of error in the remote sensing estimates. The analysis is preceded by a background discussion on microwave interaction theory.

\section{Spaceborne Passive Microwave Remote Sensing}

In the microwave wavelength region and for temperatures typical of Earth, the RayleighJeans approximation to Planck's law of thermal radiative emission is most appropriate. The radiative power, usually expressed as a brightness temperature $\left(T_{B}\right)$, is thus proportional to physical temperature $\left(T_{S}\right)$. However, most real objects emit only a fraction of the energy a perfect emitter at the same temperature would radiate. This fraction defines the emissivity (e), such that $T_{B}$ is given by equation (1).

$$
\mathrm{T}_{\mathrm{B}}=\mathrm{eT}_{\mathrm{S}}
$$

With respect to a particular frequency and polarization, emissivity variations in the Arctic are primarily due to surface variations. For instance, emissivity at $19 \mathrm{GHz}$ vertical polarization is 0.57 for water, 0.94 for first-year ice, and 0.85 for multiyear ice (Eppler et al. 1992). Further information on microwave interaction theory is available in Ulaby et al. (1982, 1986), while the use of microwave remote sensing of sea ice is further discussed in Carsey (1992).

Spaceborne passive microwave imaging measurements began in 1968 with the Soviet Cosmos 243 (Basharinov et al. 1971). This instrument supported four nadir-looking radiometers operating from $3.5 \mathrm{GHz}$ to $37.0 \mathrm{GHz}$. Launched in 1972, the first National Aeronautics Space Agency (NASA) spaceborne imaging radiometer was the $19.35 \mathrm{GHz}$ Electronically Scanning Microwave Radiometer (ESMR; Zwally et al. 1983). Six years later, a more robust Scanning Multichannel Microwave Radiometer (SMMR) system was launched on the NASA Nimbus-7 (Gloersen et al. 1984). SMMR operated from October 1978 through August 1987 on alternating days to conserve power, and data were collected at 6.6, 10.7, 18.0, 21.0, and 37.0 GHz. Launched in 1987, the most recent additions to orbital passive microwave imaging systems are carried aboard the United States Defense Meteorological Satellite Program (DMSP) satellites. Known as the Special Sensor Microwave/Imagers (SSM/I), these instruments obtain dual polarization information at $19.4,37.0$, and $85.5 \mathrm{GHz}$, while vertical polarization data are collected at 22.2 $\mathrm{GHz}$ (Hollinger et al. 1987). SSM/I sensors have a swath width of approximately $1,400 \mathrm{~km}$, excluding a $2.4^{\circ}$ radius around the north pole, and they continue to provide daily coverage of the Arctic.

\section{Spaceborne Passive Microwave Remote Sensing of Sea Ice During Spring}

Some of the important sea ice variables to monitor during spring include sea ice concentration, extent, multiyear ice fraction, and especially snow melt onset date. Sea ice concentration is the percentage of area within a pixel that is ice covered, while sea ice extent is the 
area poleward of either the ice-ocean edge or a specified contour of sea ice concentration. Both contribute to surface albedo and control energy transfer across the OAII. Multiyear ice fraction is simply the percentage of total ice that is at least two years old. The snow melt onset date is key as it signals a dramatic shift in the energy balance. Energy absorption increases sharply with melt onset, resulting in melt pond formation and sea ice ablation over much of the Arctic.

\section{Derivation of Sea Ice Extent, Ice}

\section{Concentration, and Multiyear Ice Fraction}

In theory, the large emissivity disparity between open water and sea ice provides a convenient means to estimate sea ice extent and ice concentration using SMMR and SSM/I data. Similarly, emissivity differences between firstyear and multiyear sea ice can be exploited to estimate multiyear ice fraction. In reality, brightness temperature variations between several channels are used to differentiate open water and sea ice. For example, the NASA Team Algorithm (Cavalieri et al. 1984) uses ratios of 19 (18 on SMMR) and $37 \mathrm{GHz}$ to differentiate open water, first-year sea ice, and multiyear sea ice. Cavalieri et al. (1984) reported that the algorithm is precise to within $5 \%$ to $9 \%$ for mapping total ice concentration and $13 \%$ to $25 \%$ for multiyear ice concentration.

Gloerson and Campbell (1991) applied the NASA Team Algorithm to SMMR data and demonstrated a statistically significant decrease of $2.1 \%$ in Arctic sea ice extent from 19781987. Johannessen et al. (1995) extended the time series to 1994 with SSM/I data and reported an accelerated reduction in Arctic sea ice extent in the post-SMMR period. Recently, Cavalieri et al. (1997) examined the sea ice record from 1978 through 1996 and noted a $2.9 \%$ decrease per decade in Arctic ice extent (with a $0.4 \%$ margin of error). Further examples of sea ice products derived from the NASA Team Algorithm are available in Zwally et al. (1983), Parkinson et al. (1987), and Gloersen et al. (1992). Other sea ice concentration and extent algorithms include the AES York, NORSEX, U-Mass, and Bootstrap methods. A good description of each is provided by Steffan et al. (1992).

Uncertainties in sea ice extent, ice concentration, and multiyear ice fraction estimates stem from several sources. Instrument errors, common to all sea ice algorithms, include radiometer noise and poor calibration. Coarse spatial resolution, which leads to mixed pixels, is also a contributing factor (Cavalieri 1992). Gloersen and Cavalieri (1986) reported certain weather effects over the ocean can cause erroneous results. For instance, significant amounts of liquid water in the atmosphere will increase $\mathrm{T}_{\mathrm{B}}$. However, the microwave response is frequency dependent with $37 \mathrm{GHz}$ channels being more sensitive to clouds than $19 \mathrm{GHz}$ channels. Near surface winds also effect $T_{B}$, with horizontal polarizations being twice as sensitive as vertical polarizations (Gloersen and Barath 1977). The most significant error in sea ice extent and concentration mapping is likely due to surface emissivity variations. This is especially true for the spring transitional period, when liquid water appears in the snowpack and $T_{B}$ increases sharply. At this time, sea ice concentration estimates can be in error by as much as $50 \%$ (Steffan et al. 1992).

\section{Derivation of Snow Melt Onset Dates}

The onset of melt is characterized by an increase in $T_{B}$ and a drop in albedo owing to an increase in liquid water content within the snowpack (Chang 1984, Mätzler 1987, Onstott et al. 1987). Although the timing of snow melt on sea ice is primarily a function of the annual radiation cycle, atmospheric sensible heat forcing is responsible for interannual variability in the melt. Therefore, monitoring melt onset variations can be used to infer atmospheric conditions.

Historically, melt onset dates were determined by visually examining time series of first-year and multiyear ice fraction components of the NASA team algorithm (Anderson et al. 1985; Anderson 1987a, 1987b). For firstyear ice locations, snow melt onset was determined by the fictitious multiyear ice fraction produced by the NASA Team Algorithm. The fictitious multiyear ice fraction was the result of snow melt on the sea ice surface. For multiyear ice locations, melt onset was determined by a fictitious decline in the multiyear ice fraction as determined by the NASA Team Algorithm. However, this technique has several limitations. For example, locations had to be chosen to exclude ice advection and ice type had to be known before melt. Furthermore, there was no way to automate melt onset determination. 

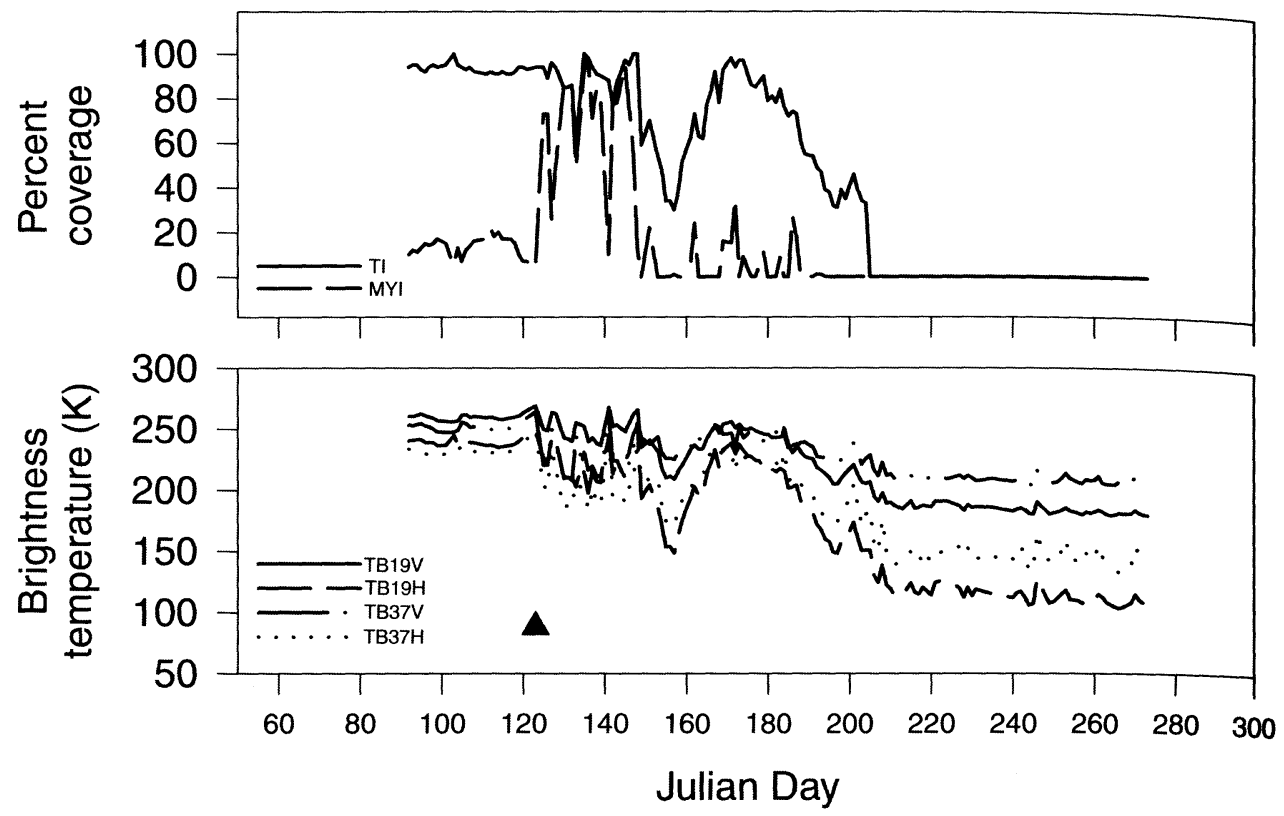

Figure 1: Time series analysis of ice coverage and brightness temperature for a first-year sea ice location in the Laptev Sea $\left(72^{\circ} \mathrm{N}, 135^{\circ} \mathrm{E}\right)$ in 1990 . The triangle represents the melt onset date as determined by the Anderson (1997) algorithm.
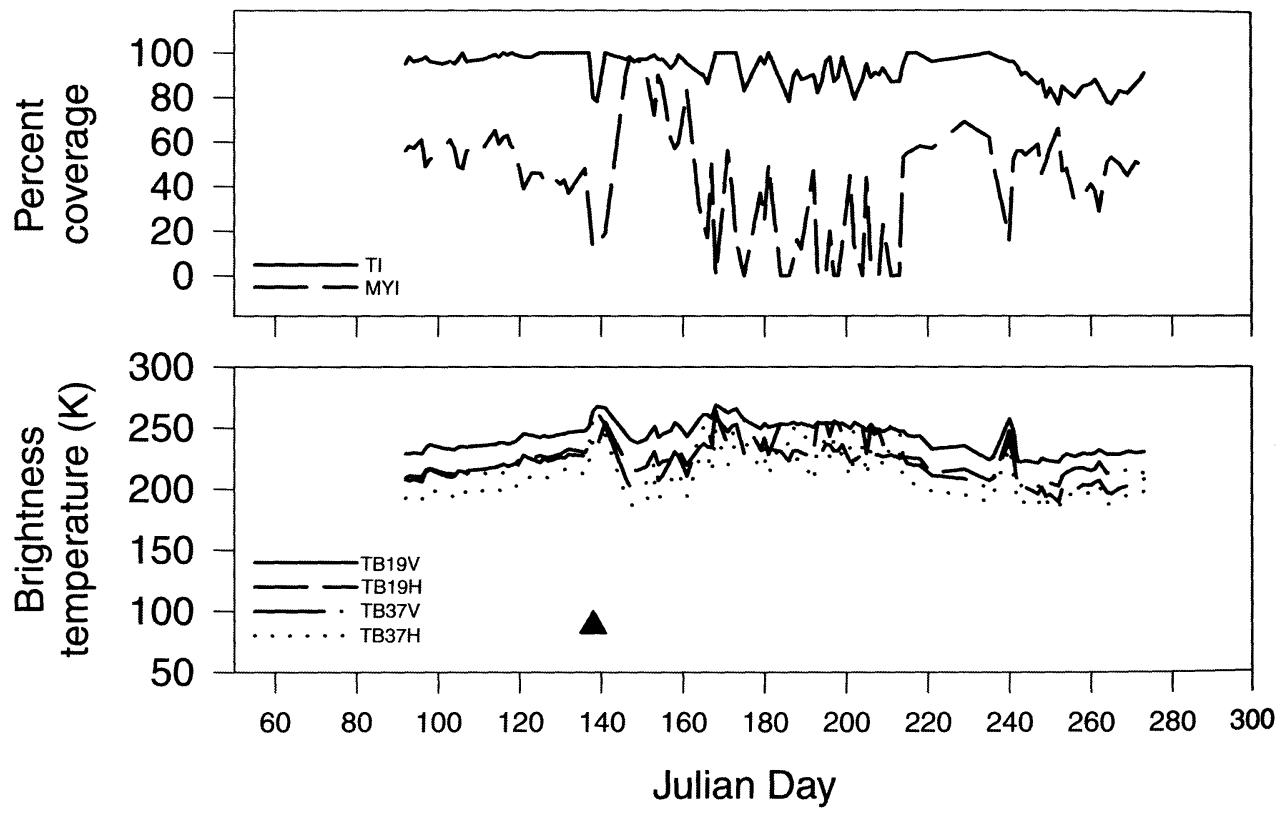

Figure 2: Time series analysis of ice coverage and brightness temperature for a multiyear sea ice location in the Arctic Ocean $\left(83^{\circ} \mathrm{N}, 180^{\circ} \mathrm{W}\right)$ in 1990 . The triangle represents the melt onset date as determined by the Anderson (1997) algorithm. 
Table 1 Comparisons between Active and Passive Microwave Derived Melt Onset Dates

\begin{tabular}{|c|c|c|c|c|c|c|}
\hline $\begin{array}{l}\text { Buoy } \\
\text { Number }\end{array}$ & Lat, Long & $\begin{array}{c}\text { First Day Buoy } \\
\text { Temperatures } \\
\text { Are Over } \\
\text { Freezing }\end{array}$ & $\begin{array}{c}\text { First Period Buoy } \\
\text { Temperatures Are } \\
\text { Over Freezing }\end{array}$ & $\begin{array}{c}\text { Extended } \\
\text { Period Buoy } \\
\text { Temperatures Are } \\
\text { Above Freezing }\end{array}$ & $\begin{array}{c}\text { Active } \\
\text { Microwave } \\
\text { Melt Onset } \\
\text { Date* }\end{array}$ & $\begin{array}{c}\text { Passive } \\
\text { Microwave } \\
\text { Melt Onset } \\
\text { Date }\end{array}$ \\
\hline 7100 & 74,140 & May 13 & May 22 & June 17 & June 14 & May 22 \\
\hline 12800 & 77,158 & May 22 & June 1 & June 14 & June 15 & May 22 \\
\hline 12801 & 79,135 & June 16 & June 16 & June 16 & June 18 & June 29 \\
\hline 12806 & 73,155 & May 23 & May 31 & June 8 & May 23 & May 22 \\
\hline 12807 & 83,152 & July 6 & July 6 & July 6 & June 19 & June 20 \\
\hline 12808 & $74.5,128$ & June 18 & June 18 & June 18 & June 17 & June 20 \\
\hline
\end{tabular}

*Active dates are adapted from Winebrenner et al. (1994).

An automated threshold algorithm was then developed by Anderson (1997) to identify melt onset for any Arctic location, independent of ice type. The algorithm defined the onset of melt when the difference between the $19 \mathrm{GHz}$ horizontal channel and the $37 \mathrm{GHz}$ horizontal channel was less than $2 \mathrm{~K}$. Using the horizontal difference and setting the threshold value was accomplished through multiple case studies.

To illustrate the Anderson (1997) snow melt onset algorithm, two time-series plots of $T_{B}$ are shown, one for a first-year ice location in the Laptev Sea (Fig. 1) and another for a multiyear ice location in the central Arctic Ocean (Fig. 2). In both cases, rapid $T_{B}$ increases are followed by a decrease in $T_{B}$, likely due to snow grain metamorphism. The onset of melt is defined as occurring after Julian day 122 for the first-year location (Fig. 1) and after Julian day 140 for the multiyear location (Fig. 2).

Using active microwave data, Winebrenner et al. (1994) have also developed a melt onset algorithm which assigns a melt date after a threshold is exceeded. Winebrenner et al. (1994) also compared the active microwave data to buoy and satellite derived surface temperatures. For the majority of the occasions that the active microwave algorithm was triggered by the melt onset, temperatures were near to or above freezing and remained above freezing. When the Anderson (1997) algorithm is applied to passive microwave data for the same locations and compared to the active microwave data similar results are found (Table 1).

To illustrate in more detail the use of passive microwave data for climate studies, melt onset dates have been determined from 1988-1992 using the Anderson (1997) algorithm to show interannual variations (Table 2). The locations used were the same as in Anderson (1987a) and are shown in Figure 3. Results show that some locations have large differences in the melt onset date between years. For example, the firstyear ice location in the Laptev Sea (used in Fig. 1) has a 48-day difference between the earliest

Table 2 Melt Onset Dates for Various Locations Around the Arctic

\begin{tabular}{rlccccccc}
\hline & & \multicolumn{7}{c}{ Melt Onset Date } \\
\cline { 3 - 8 } Point & Location & $\mathbf{1 9 8 8}$ & $\mathbf{1 9 8 9}$ & $\mathbf{1 9 9 0}$ & $\mathbf{1 9 9 1}$ & $\mathbf{1 9 9 2}$ & Mean & SD \\
\hline 1 & Laptev Sea (FYI) & 171 & 134 & 123 & 129 & 141 & 140 & 19 \\
2 & East Siberian Sea (FYI) & 165 & 99 & $92^{*}$ & $91^{*}$ & 157 & 121 & 37 \\
3 & Chukchi Sea (FYI) & 161 & 141 & 101 & 142 & 143 & 138 & 25 \\
4 & Chukchi Sea (FYI) & 120 & 96 & 115 & 111 & 94 & 107 & 10 \\
5 & Laptev Sea (MYI) & 176 & 169 & 149 & 147 & 125 & 153 & 14 \\
6 & Barents Sea (FYI) & 135 & 104 & 103 & 98 & 126 & 113 & 17 \\
7 & Arctic Ocean (MYI) & 163 & 174 & 138 & 158 & 172 & 161 & 15 \\
8 & Arctic Ocean (MYI) & 163 & 174 & 138 & 185 & 172 & 166 & 20 \\
9 & Arctic Ocean (MYI) & 182 & 173 & 157 & 186 & 172 & 174 & 13 \\
10 & Baffin Bay (FYI) & 157 & 108 & 115 & 122 & 113 & 123 & 22 \\
11 & Hudson Bay (FYI) & 123 & 104 & 93 & $97^{*}$ & $92^{*}$ & 102 & 13 \\
12 & Hudson Bay (FYI) & 123 & 117 & $92^{*}$ & 111 & 128 & 114 & 13 \\
13 & Hudson Bay (FYI) & 100 & 134 & $93^{*}$ & 111 & 99 & 107 \\
\hline
\end{tabular}

* First date of analysis. 


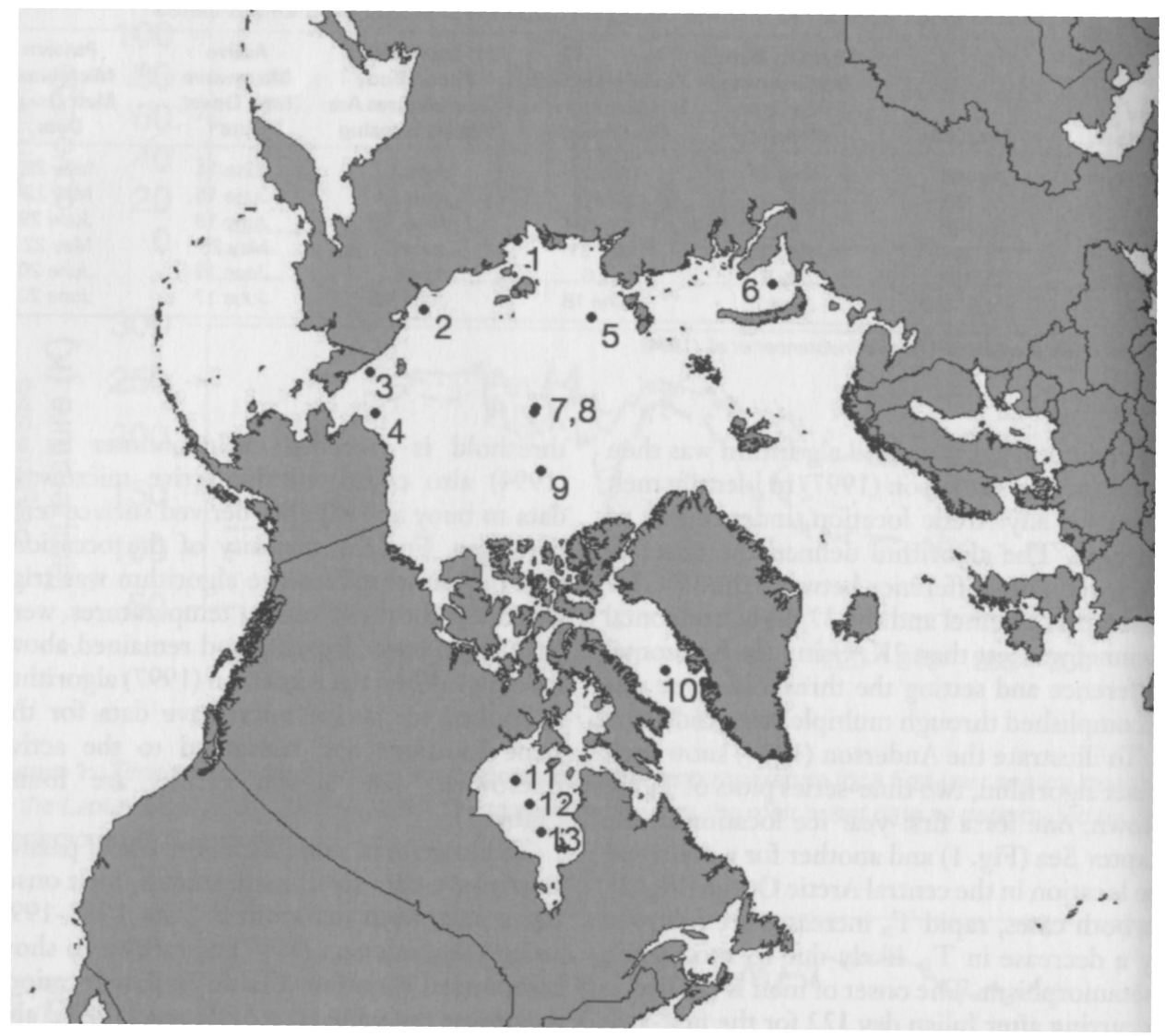

Figure 3: Case study sites used in Anderson (1987a) to compute a snow melt onset algorithm.

melt date (Julian day 123) and the latest (Julian day 171). The East Siberian Sea site had an even greater variation of 74 days. Other firstyear ice locations are much more consistent between the onset of melt dates. Multiyear ice locations also show variations between years, though they are smaller than the first-year ice locations.

\section{Conclusions and Future Prospects}

Sea ice is a critical component of the spring Arctic climate because it influences albedo and controls energy transfer across the OAII. The onset of snow melt is marked by a rapid increase in energy absorption as albedo decreases, harboring the coming seasonal melt. This paper outlined the utility of using space- borne passive microwave remote sensing to derive important sea variables during the spring period. It presented basic concepts of microwave interaction theory, and it noted some of the important spaceborne passive microwave remote sensing instruments. This paper explained the derivation of sea ice extent, concentration, and snow melt onset, and it provided comments on the accuracy and precision of the remote estimates, with special attention to sources of error.

The continued launching of satellites such as SSM/I ensures that a long, continuous data record will be accrued, while the development of new sensors, such as the Advanced Microwave Scanning Radiometer (AMSR), promises to provide better spatial resolution. Continued algorithm development promises to provide 
better precision and accuracy to the remote sensing estimation of spring-time sea ice variables. Understanding and characterizing results from this newer generation of satellites and algorithms may hold the potential to define the role of sea ice in Earth's climate with greater precision.

\section{Literature Cited}

Anderson, Mark R. 1987a. The onset of spring melt in first-year ice regions of the Arctic as determined from SMMR data for 1979 and 1980. Fournal of Geophysical Research 92:13,153-63.

1987b. Snow melt on sea ice surfaces as determined from passive microwave satellite data. In Large Scale Effects of Seasonal Snow Cover, ed. Barry E. Goodison, Roger G. Barry, and Jeff Dozier, 329-52. Wallingford, UK: IAHS Publication No. 166.

1997. Determination of a melt onset date for Arctic sea ice regions using passive microwave data. Annals of Glaciology 25:382-7.

Anderson, Mark R., Robert G. Crane, and Roger G. Barry. 1985. Characteristics of Arctic Ocean ice determined from SMMR data for 1979: Case studies in the seasonal sea ice zone. Advances in Space Research 5:257-61.

Basharinov, A.E., A.S. Gurvich, S.T. Egorov, V.I. Zhukov, A.A. Kurskaya, L.I. Malafeev, D.T. Mateev, A.S. Mikhailov, and A.M. Shutko. 1971. Results of observations of the thermal radio emission of earth's surface in an experiment on the Cosmos243 satellite. Kosmonaut Issled 9:268-73.

Carsey, Frank D. 1992. Microwave Remote Sensing of Sea Ice. Washington, DC: American Geophysical Union Monograph 68.

Cavalieri, Donald J. 1992. The validation of geophysical products using multisensor data. In $\mathrm{Mi}$ crowave Remote Sensing of Sea Ice, ed. F. Carsey, 233-42. Washington, DC: American Geophysical Union Monograph 68.

Cavalieri, Donald J., Per Gloersen, and William J. Campbell. 1984. Determination of sea ice parameters with the Nimbus 7 SMMR. Fournal of Geopbysical Research 89(D4):5355-69.

Cavalieri, Donald J., Per Gloersen, Claire L. Parkinson, Josefino C. Comiso, and H. Jay Zwally. 1997. Observed hemispheric asymmetry in global sea ice changes. Science 278:1104-6.

Chang, Albert T.C. 1984. Microwave Emission from Snow. NASA Technical Memo 86177. Greenbelt, MD: Goddard Space Flight Center.

Curry, Judith A., Julie L. Schramm, and Elizabeth E. Ebert. 1995. Sea ice-albedo climate feedback mechanism. Fournal of Climate 8:240-7.

Eppler, Duane T., L. Dennis Farmer, Alan W. Lohanick, Mark R. Anderson, Donald J. Cavalieri,
Josefino Comiso, Per Gloersen, Caren Garrity, Thomas C. Grenfell, Martti Hallikainen, James A. Maslanik, Christian Mätzler, Rae A. Melloh, Irene Rubinstein, and Calvin T. Swift. 1992. Passive microwave signatures of sea ice. In Microwave Remote Sensing of Sea Ice, ed. F. Carsey, 47-71. Washington, DC: American Geophysical Union Monograph 68.

Gloersen, Per, and Francis Barath. 1977. A scanning multichannel microwave radiometer for Nimbus$\mathrm{G}$ and Seasat-A. IEEE Journal of Oceanic Science 2(2):172-8.

Gloersen, Per, and William J. Campbell. 1991. Recent variations in Arctic and Antarctic sea-ice covers. Nature 352:33-6.

Gloersen, Per, and Donald J. Cavalieri. 1986. Reduction of weather effects in the calculation of sea ice concentration from microwave radiances. Fournal of Geophysical Research 91(C3):3913-9.

Gloersen, Per, William J. Campbell, Donald J. Cavalieri, Josefino Comiso, Claire L. Parkinson, and H. Jay Zwally. 1992. Arctic and Antarctic Sea Ice, 1978-1987: Satellite Passive-Microwave Observations and Analysis. Washington, DC: NASA SP511.

Gloersen, Per, Donald J. Cavalieri, Albert T.C. Chang, Thomas T. Wilheit, D.B. Ross, D. Staelin, E.R.L. Windsor, Francis Barath, P. Gudmandsen, E. Langham, and Rene O. Ramseir. 1984. A summary of results from the first Nimbus-7 SMMR observations. Fournal of Geophysical Research 89(D4): 5335-44.

Hollinger, Jim P., J.L. Pierce, and Gene A. Poe. 1990 SSM/I instrument evaluation. IEEE Transactions on Geoscience and Remote Sensing 28:781-90.

International Panel on Climate Change (IPCC). 1998. Chapter 3: The Arctic and Antarctic. In The Regional Impacts of Climate Change: An Assessment of Vulnerability, ed. Robert T. Watson, Marufu C. Zinyowera, and Richard H. Moss, 85-104. New York: Cambridge University Press.

Johannessen, Ola M., Martin Miles, and E. Bjorgo. 1995. The Arctic's shrinking sea ice. Nature 376: 126-7.

Mätzler, Christian. 1987. Applications of the interaction of microwaves with the natural snow cover. Remote Sensing Reviews 2:259-87.

Onstott, Robert G., Thomas C. Grenfell, Christian Mätzler, Chuck A. Luther, and Einar A. Svendsen. 1987. Evolution of microwave sea ice signatures during early summer and midsummer in the marginal ice zone. Fournal of Geophysical Research 92:6825-35.

Parkinson, Claire L., Josefino Comiso, H. Jay Zwally, Donald J. Cavalieri, Per Gloersen, and Willaim J. Campbell. 1987. Arctic Sea Ice, 19731976: Satellite Passive Microwave Observations. Washington, DC: NASA SP-489.

Steffan, Koni, Jeffery Key, Donald J. Cavalieri, Jo- 
sefino Comiso, Per Gloersen, Karen St. Germain, and Irene Rubinstein. 1992. The estimation of geophysical parameters using passive microwave algorithms. In Microwave Remote Sensing of Sea Ice, ed. F. Carsey, 201-31. Washington, DC: American Geophysical Union Monograph 68.

Ulaby, Frank T., Richard K. Moore, and Adrian K. Fung. 1982. Microwave Remote Sensing: Active and Passive: Volume II: Radar Remote Sensing and Surface Scattering and Emission Theory. Reading, MA: Addison-Wesley Publishing Company. 1986. Microwave Remote Sensing: Active and Passive: Volume III: From Theory to Application. Reading, MA: Addison-Wesley Publishing Company.

Vowinckel, E., and S. Orvig. 1970. The climate in the north polar basin. In Climate of the Polar Regions, Vol.14, World Survey of Climatology, 129-252. Amsterdam: Elsevier.

Winebrenner, Dale P., E.D. Nelson, Roger Colony, and R.D. West. 1994. Observation of melt onset on multiyear Arctic sea ice using the ERS 1 syn- thetic aperture radar. Fournal of Geophysical. Research 99(C11):22,425-41.

Zwally, H. Jay, Josefino Comiso, Claire L. Parkinson, William J. Campbell, Frank Carsey, and Per Gloersen. 1983. Antarctic Sea Ice, 1973-1976: Satellite Passive-Microwave Observations. Washington, DC: NASA Special Publication SP-459.

SHELDON DROBOT is a PhD Candidate in the Department of Geosciences, University of NebraskaLincoln, Lincoln, NE 68588-0340. His research interests include remote sensing, polar climatology, and climate change.

MARK R. ANDERSON is an Associate Professor in the Department of Geosciences, University of Nebraska-Lincoln, Lincoln, NE 68588-0340. His research interests include polar meteorology/climatology, microwave remote sensing in the cryosphere, and synoptic/mesoscale meteorology. 